\title{
Pengaruh Tindak Lanjut Hasil Pemeriksaan Terhadap Kualitas Laporan Keuangan Dengan Tingkat Pengungkapan Laporan Keuangan Sebagai Variabel Moderating (Studi Empiris Pada Kementerian/Lembaga Republik Indonesia)
}

\author{
Fera Tresnawati $^{1}$ R. Nelly Nur Apandi ${ }^{2}$ \\ Program Studi Akuntansi, Fakultas Pendidikan Ekonomi dan Bisnis, \\ Universitas Pendidikan Indonesia, Bandung, Indonesia
}

\begin{abstract}
This study aims to determine the effect of follow-up examination results on the quality of financial statements with the level of financial statement disclosure as a moderating variable. This research uses a quantitative approach with descriptive research design and associative research. The sample of this study using 85 Ministries / Institutions in Indonesia in 2014. Data analysis techniques using binary logistic regression analysis. The test results show that the follow-up of examination results positively affect the quality of financial statements, the level of disclosure of financial statements have a positive effect on the quality of financial statements and the level of financial statement disclosure is not able to moderate the influence of follow-up examination results on the quality of financial statements.
\end{abstract}

Keywords: Follow-up of Inspection Result, Quality of Financial Statement, Financial Statement Disclosure Level

Abstrak. Penelitian ini bertujuan untuk mengetahui pengaruh tindak lanjut hasil pemeriksaan terhadap kualitas laporan keuangan dengan tingkat pengungkapan laporan keuangan sebagai variabel moderating. Penelitian ini menggunakan pendekatan kuantitatif dengan desain penelitian deskriptif dan penelitian asosiatif. Sampel penelitian ini menggunakan 85 Kementerian/Lembaga di Indonesia pada tahun 2014. Teknik analisis data menggunakan analisis binary logistic regression. Hasil pengujian menunjukkan bahwa tindak lanjut hasil pemeriksaan berpengaruh positif terhadap kualitas laporan keuangan, tingkat pengungkapan laporan keuangan berpengaruh positif terhadap kualitas laporan keuangan dan tingkat pengungkapan laporan keuangan tidak mampu memoderasi pengaruh tindak lanjut hasil pemeriksaan terhadap kualitas laporan keuangan.

Kata Kunci: Tindak Lanjut Hasil Pemeriksaan, Kualitas Laporan Keuangan, Tingkat Pengungkapan Laporan Keuangan

Corresponding Author. Email. feraakuntansi@gmail.com ${ }^{1}$, nellynurapandi.upi@ gmail.com ${ }^{2}$

How to Cite This Article. Tresnawati, F., \& Apandi, N.N.R. (2016). Pengaruh Tindak Lanjut Hasil Pemeriksaan Terhadap Kualitas Laporan Keuangan Dengan Tingkat Pengungkapan Laporan Keuangan Sebagai Variabel Moderating (Studi Empiris Pada Kementerian/Lembaga Republik Indonesia). Jurnal Akuntansi Riset.. Program Studi Akuntansi. Fakultas Pendidikan Ekonomi dan Bisnis Universitas $\begin{array}{llllll}\text { Pendidikan } & \text { Indonesia, } & 8 & (1), & 13-24 & \text { Retrieved }\end{array}$ http://ejournal.upi.edu/index.php/aset/article/view/4017

History of article. Received: January 2016, Revision: Maret 2016, Published: June 2016

Online ISSN: 2541-0342. Print ISSN: 2086-2563. DOI : 10.17509/jaset.v8i1.4017

Copyright@2016. Jurnal ASET (Akuntansi Riset) Program Studi Akuntansi FPEB UPI 


\section{PENDAHULUAN}

Pemerintah telah menetapkan target opini WTP atas 81 LKKL pada tahun 2014 atau 98\% dari 83 LKKL (BPK, 2015). Namun faktanya perolehan opini WTP atas Laporan Keuangan Kementerian Lembaga belum mencapai target yang telah ditetapkan. Hasil pemeriksaan BPK RI atas Laporan Keuangan kementerian/lembaga tahun 2014 menyebutkan perolehan opini sejumlah kementerian/lembaga (K/L) mengalami penurunan dibandingkan tahun sebelumnya. Pada tahun 2013 jumlah kementerian yang memperoleh opini Wajar Tanpa Pengecualian (WTP) sebanyak 65
K/L. Namun kini kementerian yang mendapat opini WTP hanya 62 kementerian. Selain itu juga pada tahun 2014 terdapat tujuh kementerian yang mendapatkan opini disclaimer dari BPK yaitu Badan Informasi Geopasial, Kementerian Pariwisata dan Ekonomi Kreatif, Kementerian Tenaga Kerja, Kementerian Komunikasi dan Informatika, LPP RRI, LPP TVRI dan Ombudsman RI (Warta BPK, 2015). Perkembangan opini LKKL dan LK BUN dalam 5 tahun terakhir (2010-2014) disajikan pada Grafik 1.1.

\section{Grafik 1.1}

Perkembangan Opini LKKL dan LKBUN Tahun 2010-2014

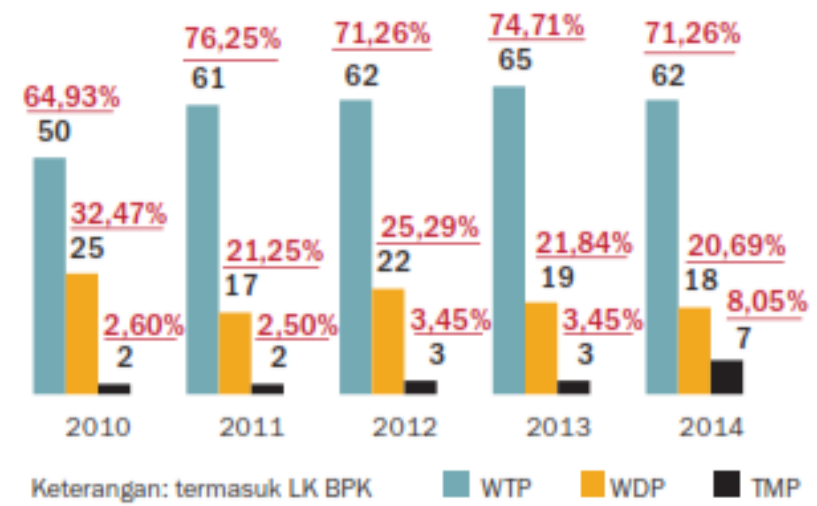

Sumber : IHPS BPK Semester 12015

Berdasarkan grafik di atas dapat disimpulkan bahwa target kualitas laporan keuangan yang harus mendapat opini dari BPK RI berupa Wajar Tanpa Pengecualian (WTP) sulit dicapai oleh sebagian kementerian dan lembaga. Penelitian Milal (2013) menunjukkan bahwa faktor utama yang menyebabkan belum tercapainya opini WTP secara penuh adalah masih adanya beberapa temuan Badan Pemeriksa Keuangan (BPK) dalam Sistem Pengendalian Intern (SPI) dan ketidakpatuhan terhadap peraturan perundang-undangan. Mustikarini \& Fitriasari (2012) mengemukakan bahwa temuan audit BPK merupakan kasus-kasus yang ditemukan BPK terhadap laporan keuangan atas pelanggaran yang dilakukan terhadap ketentuan pengendalian intern maupun terhadap ketentuan perundang- undangan yang berlaku. Hilmi \& Martani (2012) menemukan bahwa jumlah temuan BPK dalam audit LKPD berhubungan tidak signifikan mempengaruhi tingkat pengungkapan. Jumlah temuan audit BPK ternyata tidak mendorong pemerintah daerah untuk melakukan pengungkapan lebih besar. Hal ini berbeda dengan penelitian yang dilakukan oleh Liestiani (2008) bahwa jumlah temuan berhubungan positif terhadap tingkat pengungkapan.

Selain itu, rendahnya kualitas laporan keuangan disebabkan oleh rendahnya jumlah rekomendasi yang ditindaklanjuti oleh kementerian/lembaga. Selama 20102014 jumlah rekomendasi yang telah ditindaklanjuti sesuai dengan rekomendasi baru menunjukkan 60,54\% dibandingkan dengan status lainnya. Hal ini menunjukkan bahwa entitas yang diperiksa belum memperhatikan hasil pemeriksaan BPK. 
Hasil penelitian Sari, Martani \& Setyaningrum (2015) menunjukkan semakin banyak rekomendasi BPK yang ditindaklanjuti sesuai rekomendasi akan meningkatkan kualitas laporan keuangan $\mathrm{K} / \mathrm{L}$ yang direpresentasikan dari tingkat pengungkapan yang tinggi. Apabila

\section{Grafik 1.2}

Perkembangan Pemantauan Tindak Lanjut Rekomendasi Hasil Pemeriksaan

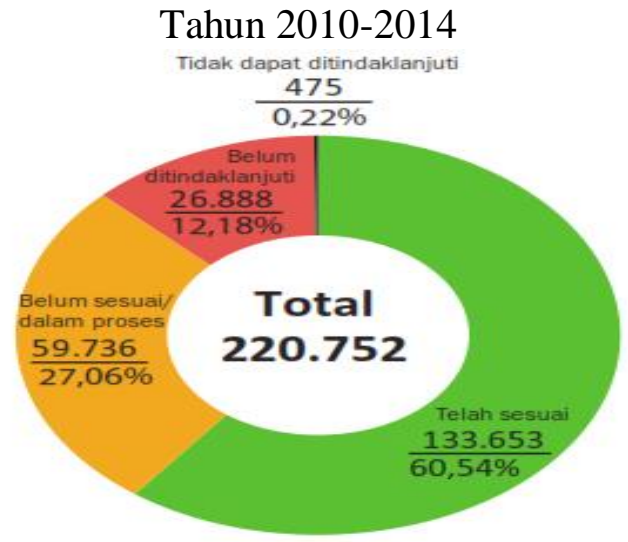

Sumber : IHPS BPK Semester 2015
Dengan menindaklanjuti hasil rekomendasi BPK, maka kementerian dan lembaga dapat memperbaiki temuan-temuan periode sebelumnya sehingga mengurangi temuan-temuan pada periode selanjutnya. Semakin besar presentase rekomendasi yang ditindaklanjuti, semakin tinggi peluang mendapatkan opini WTP. Penelitian di Cina yang dilakukan oleh, Huang dan Wang (2010) menemukan bahwa upaya auditee atau pihak terkait lainnya dalam menindaklanjuti rekomendasi hasil pemeriksaan dapat meningkatkan transparansi dan akuntabilitas pemerintah. Di Indonesia penelitian Winanti (2014) dan Setyaningrum (2015) yang menemukan bahwa tindak lanjut hasil pemeriksaan berpengaruh positif terhadap opini audit. Semakin banyak tindak lanjut pemeriksaan yang dilakukan maka pengelolaan keuangan menjadi semakin baik sehingga opini yang diperoleh pada periode selanjutnya semakin baik (Setyaningrum, 2015). Berbeda dengan Agusti (2014) dan Nurdiono, dkk. (2015) menemukan bahwa tindak lanjut hasil pemeriksaan tidak berpengaruh terhadap opini. rekomendasi tersebut telah ditindaklanjuti secara nyata dan tuntas oleh pejabat yang diperiksa sesuai dengan rekomendasi BPK, diharapkan dapat memperbaiki pengelolaan dan tanggung jawab keuangan negara pada Kementerian/Lembaga (BPK, 2015) 
FERA TRESNAWATI ${ }^{1}$ dan R. NELLY NUR APANDI ${ }^{2} /$ Pengaruh Tindak Lanjut Hasil Pemeriksaan Terhadap Kualitas Laporan Keuangan Dengan Tingkat Pengungkapan Laporan Keuangan Sebagai Variabel Moderating (Studi Empiris Pada Kementerian/Lembaga Republik Indonesia)

transparan jika telah mengungkapkan halhal yang dipandang perlu untuk diungkapkan dalam Catatan atas laporan keuangan (CALK). CALK ditunjukkan untuk memperkuat atau memperjelas pospos yang disajikan dalam bagian utama laporan keuangan. Dalam kebanyakan kasus, semua data diperlukan pembaca, tidak dapat disajikan dalam laporan keuangan itu sendiri, oleh karenanya laporan tersebut mencakup informasi yang esensial harus disajikan dalam catatan atas laporan keuangan. Tingkat pengungkapan yang makin mendekati pengungkapan penuh (full disclosure) akan mengurangi asimetri informasi. Semakin lengkap informasi yang diungkapkan dalam CALK (full disclosure) maka pembaca laporan keuangan akan semakin mengerti kinerja pengelolaan keuangan.

Menurut Mutasowifin (2008, hlm. 34) laporan keuangan yang berkualitas dapat mencerminkan gambaran yang akurat tentang kondisi dan kinerja keuangan entitas. Semakin tajam dan semakin jelas gambar yang disajikan dalam laporan keuangan, dan semakin mendekati realitas keuangan maka semakin tinggi pula kualitas laporan keuangan Menurut Sugiono \& Untung (2008, hlm. 8-9) laporan keuangan yang berkualitas adalah laporan yang otentik, obyektif dan bisa dipercaya. Tingkat kepercayaan ini ditentukan oleh opini/ pendapat yang diberikan auditor. Akbar (2015, hlm. 53) menjelaskan bahwa ada beberapa opini yang diberikan oleh auditor yaitu Opini Wajar Tanpa Pengecualian

$$
\ln \frac{U n q_{i t}}{1-U n q_{i t}}=\beta_{0}+\beta_{1} T L H P_{i t-1}+\beta_{2} D I S C_{i t}+\beta_{a} T L H P_{i t-1} * D I S C_{i t}+\varepsilon
$$

Keterangan:

Unq $=$ probabilitas menerima opini Unqualified

$\alpha \quad=$ konstanta

$\beta_{1}-\beta_{3}=$ koefisien regresi

TLHP = Tindak Lanjut Hasil Pemeriksaan

DISC $=$ Disclosure $\quad$ (Tingkat

Pengungkapan)

e = eroor term

\section{HASIL DAN PEMBAHASAN}

(WTP)/ Unqualified Opinion, Opini Wajar Dengan Pengecualian (WDP)/ Qualified Opinion, Opini Tidak Wajar/ Adverse Opinion dan Pernyataan menolak memberikan opini / Disclaimer Opinion.

\section{METODOLOGI PENELITIAN}

Penelitian ini menggunakan pendekatan kuantitatif dengan desain penelitian deskriptif dan penelitian asosiatif. Jenis data yang digunakan dalam penelitian ini adalah data kuantitatif. Data-data yang dikumpulkan berupa Laporan Keuangan Kementerian Lembaga (LKKL) dan Laporan Hasil Pemeriksaan BPK RI. Data sekunder tersebut diperoleh dari Pusat Informasi dan Komunikasi BPK RI. Pengumpulan data menggunakan metode dokumentasi. Populasi dalam penelitian ini adalah Kementerian/Lembaga di Republik Indonesia baik yang berbentuk kementerian, lembaga tinggi negara, lembaga negara maupun badan yang diperiksa oleh Badan Pemeriksa Keuangan berjumlah 85 Kementerian/ Lembaga. Dalam penelitian ini kualitas laporan keuangan sebagai variabel dependen merupakan variabel kategorik atau dummy (WTP diberi kode 1 dan selain WTP diberi kode 0 ). Analisis data dalam penelitian ini mengunakan statistik deskriptif dan analisis binary regresi logistik.

Persamaan model binary regresi logistik yang digunakan dalam penelitian ini adalah sebagai berikut:

Hasil pengujian memberikan dua nilai -2 Log Likelihood yaitu pertama pada saat variabel independen tidak dimasukkan ke dalam model dengan jumlah sampel sebanyak 85 mendapatkan nilai $-2 \quad$ Log 
Likelihood sebesar 89,595 ini yang kedua dengan memasukkan variabel signifikan pada alpha $5 \%$ dan hipotesis nol ditolak yang berarti model dengan konstanta saja tidak fit dengan data. -2 Log Likelihood independen menjadi 73, 635 sehingga model fit dengan data.

Tabel 1.1 Perbandingan (-2 Log likelihood) awal dan akhir

\begin{tabular}{|c|c|}
\hline $\begin{array}{c}\text {-2 Log Likelihood (-2 LL ) pada awal (model } \\
\text { dengan hanya memasukkan konstanta }\end{array}$ & 101,245 \\
\hline $\begin{array}{c}-2 \text { Log Likelihood (-2LL) pada akhir (model } \\
\text { dengan konstanta dan variabel independen ) }\end{array}$ & 86,987 \\
\hline
\end{tabular}

Sumber : data diolah, 2016

Data tabel di atas menujukkan penurunan nilai -2 LL awal sebesar 101,245 menjadi 86,98. Selisih kedua -2 LL sebesar 14,191 maka nilai Chi Square hitung lebih besar daripada Chi Square tabel pada df 3 yaitu $14,191>7,82$. Oleh karena selisih penurunan -2 Log Likelihood signifikan berarti penambahan variabel independen ke dalam model memperbaiki model fit.
Untuk melihat kemampuan variabel independen dalam menjelaskan variabel dependen digunakan nilai Cox \& Snell $R$ Square dan Nagelkerke R Square.

Tabel 1.2 Uji Cox and Snell's R Square dan Nagelkerker's $R$

\begin{tabular}{|c|c|c|c|}
\hline Step & $\begin{array}{c}-2 \text { Log } \\
\text { likelihood }\end{array}$ & $\begin{array}{c}\text { Cox \& Snell } \\
R \text { Square }\end{array}$ & $\begin{array}{c}\text { Nagelkerke } R \\
\text { Square }\end{array}$ \\
\hline 1 & 86.987 & .154 & .221 \\
\hline
\end{tabular}

Sumber : data diolah, 2016

Berdasarkan tabel di atas nilai Nagelkerke R Square sebesar 0,221 dan Cox \& Snell $R$ Square sebesar 0,154. Hal ini menujukkan bahwa kemampuan variabel independen dalam menjelaskan variabel dependen adalah sebesar 0,274 atau sebesar $22,1 \%$ dan terdapat $77,9 \%$ faktor lain di luar model yang menjelaskan variabel dependen. Jika nilai Hosmer and Lemeshow's Goodness of fit test statistics sama dengan atau kurang dari 0,05 maka hipotesis nol ditolak yang berarti bahwa ada perbedaan signifikan antara model dengan nilai observasinya sehingga goodness of fit model tidak baik karena model tidak dapat memprediksi nilai observasinya. Jika nilai Hosmer and Lemeshow's Goodness of fit test statistics lebih besar dari 0,05 maka hipotesis nol tidak ditolak yang berarti model mampu memprediksi nilai observasinya atau dikatakan model dapat diterima karena cocok dengan data observasinya (Ghozali, 2013, hlm. 341).

Tabel 1.3 Hosmer and Lemeshow Test

\begin{tabular}{|c|r|r|r|}
\hline Step & Chi-square & Df & \multicolumn{1}{c|}{ Sig. } \\
\hline 1 & 7.680 & 7 & .362 \\
\hline \multicolumn{4}{|c}{ Sumber : data diolah, 2016} \\
\hline
\end{tabular}

Nilai Hosmer and Lemeshow Test sebesar 7.680 dengan taraf signifikansi sebesar 0,362 yang nilainya lebih besar dari 0,05 . Dengan demikian model mampu meprediksi nilai observasinya atau dapat dikatakan model dapat diterima karena cocok dengan data observasinya. Kekuatan prediksi dari model regresi untuk 


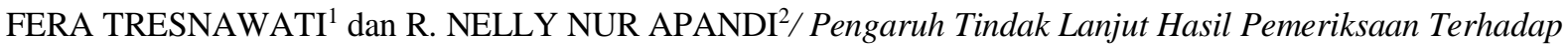
Kualitas Laporan Keuangan Dengan Tingkat Pengungkapan Laporan Keuangan Sebagai Variabel Moderating (Studi Empiris Pada Kementerian/Lembaga Republik Indonesia)

memprediksi peluang mendaatkan opini

Unqualified oleh kementerian/ lembaga

ditunjukkan pada matriks klasifikasi.

Tabel 1.4 Matriks Klasifikasi

\begin{tabular}{|c|c|c|c|c|c|}
\hline \multicolumn{3}{|c|}{ Observed } & \multicolumn{3}{|c|}{ Predicted } \\
\hline & & & \multicolumn{2}{|c|}{ KLP } & \multirow{2}{*}{$\begin{array}{c}\text { Percentage } \\
\text { Correct }\end{array}$} \\
\hline & & & .00 & 1.00 & \\
\hline \multirow[t]{3}{*}{$\overline{\text { Step } 1}$} & KLP & .00 & 7 & 17 & 29.2 \\
\hline & & 1.00 & 2 & 59 & 96.7 \\
\hline & $\begin{array}{r}\mathrm{O} \\
\text { Per }\end{array}$ & $\begin{array}{l}\text { ll } \\
\text { age }\end{array}$ & & & 77.6 \\
\hline
\end{tabular}

Sumber : data diolah, 2016

Tabel di atas menunjukkan nilai overall percentage sebesar $77.6 \%$ yang berarti ketepatan model penelitian ini adalah sebesar $77.6 \%$.

Tabel 1.5 Hasil Pengujian Hipotesis

\begin{tabular}{|c|c|c|c|}
\hline Variabel & Prediksi & Koefisien & Kesimpulan \\
\hline TLHP & Positif & 0.209 & $\mathrm{H}_{1}$ Diterima \\
\hline DISC & Positif & 0.361 & $\mathrm{H}_{2}$ Diterima \\
\hline TLHP_DISC & Positif & $-0,003$ & $\mathrm{H}_{3}$ Ditolak \\
\hline \multicolumn{4}{|c|}{$\begin{array}{l}\text { Variabel Dependen : KLP = Kualitas Laporan Keuangan (Unqualified =1, Nor } \\
\text { Unqualified = 0); Variabel Independen : TLHP = Tindak lanjut hasi } \\
\text { pemeriksaan , DISC = Tingkat pengungkapan laporan keuangan ; Variabe } \\
\text { Moderating : TLHP_DISC = interaksi antara tindak lanjut hasil pemeriksaan \& } \\
\text { tingkat pengungkapan laporan keuangan }\end{array}$} \\
\hline
\end{tabular}

Sumber : data diolah, 2016

Hasil pengujian binary logistic Berdasarkan tabel di atas regression menujukkan bahwa tindak lanjut menunjukkan model regresi yang terbentuk hasil pemeriksaan berpengaruh positif adalah sebagai berikut :

$$
\begin{gathered}
\operatorname{Ln} \frac{U n q_{i t}}{1-U n q_{i t}} \\
=-23,569+0,209 \text { TLHP }+0,361 \text { DISC }- \\
\text { 0,003TLHP_DISC }+\mathrm{e}
\end{gathered}
$$

Pengaruh Tindak Lanjut Hasil Pemeriksaan terhadap Kualitas Laporan Keuangan terhadap kualitas laporan keuangan. Hal ini ditujukkan dengan koefisien positif sebesar 0,209 . Tindak lanjut hasil pemeriksaan dapat memperbaiki kualitas laporan keuangan. Semakin tinggi tindak lanjut hasil rekomendasi maka semakin baik kualitas laporan keuangan.

Tindak lanjut hasil pemeriksaan periode lalu merupakan upaya untuk memperbaiki temuan pemeriksaan berdasarkan rekomendasi yang diberikan 
oleh auditor, sehingga pada periode selanjutrnya temuan yang sama tidak terulang. Tindak lanjut hasil pemeriksaan tahun lalu akan menjadi pertimbangan auditor dalam menetukan risiko audit. Selain itu upaya kementerian/ lembaga dalam menindaklanjuti rekomendasi hasil pemeriksaan dapat memperbaiki sistem pengelolaan keuangan sehingga tidak akan ditemukan lagi adanya kelemahan pengendalian internal dan ketidakpatuhan terhadap peraturan perundang-undangan.

Pengendalian internal yang efektif pada tahun berjalan dapat memberikan gambaran kepada para pemangku kepentingan bahwa kemungkinan salah saji dalam laporan keuangan pada tahun selanjutnya juga relatif kecil. Ketepatan dalam proses penginputan dan pemprosesan transaksi sangat penting dalam meningkatkan akurasi saldo akun pada laporan keuangan. Semakin efektif pengendalian internal faktor-faktor terkait kecurangan terhadap laporan keuangan atau penyalahgunaan aset dapat diminimalisir. Jika efektifitas pengendalian internal meningkat berarti catatan entitas dapat diandalkan serta aktiva entitas dapat dilindungi. Dengan demikian resiko salah saji dapat dihindari dan laporan keuangan disajikan lebih akurat. Selanjutnya dapat dipastikan kualitas laporan keuangan yang dihasilkan akan semakin baik dan kriteria pemberian opini akan terpenuhi sehingga peluang untuk mendapatkan opini WTP akan semakin besar.

Hasil penelitian ini didukung oleh teori yang diungkapkan oleh Djalil (2014, hlm. 363) rekomendasi BPK selain untuk menyelesaikan permasalahan yang diungkap dalam laporan hasil pemeriksaan, juga untuk memperbaiki sistem pengelolaan keuangan yang akuntabel dan transparan sehingga tidak ditemukan lagi adanya kelemahan pengendalian internal dan ketidakpatuhan terhadap peraturan perundang-undangan. Semakin tinggi presentase jumlah rekomendasi yang selesai ditindaklanjuti semakin akuntabel pengelolaan keuangan.
Hal ini selaras dengan hasil penelitian Winanti (2014) dan Setyaningrum (2015) yang menemukan bahwa tindak lanjut hasil pemeriksaan berpengaruh positif terhadap opini audit. Semakin banyak tindak lanjut pemeriksaan yang dilakukan maka pengelolaan keuangan menjadi semakin baik sehingga opini yang diperoleh pada periode selanjutnya semakin baik.

\section{Pengaruh Tingkat Pengungkapan Laporan Keuangan Terhadap Kualitas Laporan Keuangan}

Variabel tingkat pengungkapan laporan keuangan memiliki nilai koefisen regresi 0,361. Hasil pengujian ini menunjukkan bahwa tingkat pengungkapan laporan keuangan berpengaruh positif signifikan terhadap kualitas laporan keuangan, sehingga $\mathrm{H}_{2}$ diterima. Semakin tinggi tingkat pengungkapan laporan keuangan maka semakin baik pula kualitas laporan keuangan.

Pengungkapan informasi berdampak material yang dilakukan oleh manajemen akan membantu stakeholder dalam memahami kinerja keuangan entitas. Oleh karena itu laporan keuangan harus memuat informasi yang memadai terhadap semua aspek yang material. Dalam memutuskan apakah pengungkapan informasi telah memadai harus didasarkan apakah informasi tambahan akan berdampak material terhadap pengambilan keputusan. Komitmen manajemen untuk mengungkapkan informasi memadai dapat terlihat pada tingkat pengungkapan laporan keuangan yang dilakukan. Menurut Djalil (2014, hlm. 404) dalam kebanyakan kasus, semua data diperlukan pembaca, tidak dapat disajikan dalam laporan keuangan itu sendiri, oleh karenanya laporan tersebut mengandung informasi yang esensial harus disajikan dalam catatan atas laporan keuangan. Catatan atas laporan keuangan ditunjukkan untuk memperkuat atau memperjelas pospos yang disajikan dalam bagian utama laporan keuangan. Tingkat pengungkapan yang makin mendekati pengungkapan penuh (full disclosure) akan mengurangi asimetri 

(Studi Empiris Pada Kementerian/Lembaga Republik Indonesia)

informasi. Semakin lengkap informasi yang diungkapkan dalam CaLK (full disclosure) maka pembaca laporan keuangan akan semakin mengerti kinerja pengelolaan keuangan.

Tingkat pengungkapan yang tinggi dapat menurunkan risiko informasi. Dengan demikian semakin rendah risiko informasi atas laporan keuangan maka kualitas laporan keuangan akan semakin baik. Hal ini senada seperti yang diungkapkan oleh Sari, et all (2015) bahwa kualitas laporan keuangan yang baik tercermin dari semakin tingginya tingkat pengungkapan laporan keuangan. Semakin tinggi tingkat pengungkapan laporan keuangan akan berpengaruh terhadap peluang opini yang diperoleh menjadi semakin baik.

\section{Pengaruh Tindak Lanjut Hasil Pemeriksaan Terhadap Kualitas Laporan Keuangan Dengan Tingkat Pengungkapan Laporan Keuangan Sebagai Variabel Moderating}

Pengaruh interaksi tindak lanjut hasil pemeriksaan dan tingkat pengungkapan laporan keuangan dalam penelitian ini tidak berpengaruh. Hasil pengujian hipotesis menunjukkan koefisien regresi sebesar 0,003 . Hal ini menunjukkan bahwa tingkat pengungkapan laporan keuangan tidak mampu memoderasi hubungan antara tindak lanjut hasil pemeriksaan dan kualitas laporan keuangan sehingga $\mathrm{H}_{3}$ ditolak.

Berdasarkan UU No. 15 tahun 2004 tentang pemeriksaan pengelolaan dan tanggungjawab keuangan negara opini pemeriksaan diberikan berdasarkan pada kriteria yaitu kesesuaian laporan dengan Standar Akuntansi Pemerintahan, kecukupan pengungkapan, kepatuhan terhadap peraturan perundang-undangan, dan efektivitas sistem pengendalian internal. Jika laporan keuangan suatu entitas telah memenuhi semua kriteria perumusan opini di atas, maka auditor berkewajiban memberikan opini Wajar Tanpa Pengecualian (WTP). Berdasarkan hasil analisis, rata-rata tingkat pengungkapan laporan keuangan adalah $66,14 \%$. Hal ini menujukkan bahwa tingkat pengungkapan laporan keuangan masih belum memadai. Tingkat pengungkapan laporan keuangan yang tidak memadai mengakibatkan adanya kemungkinan salah interpretasi dan kemungkinan pengaruh atas informasi yang tidak diungkapkan, baik yang sengaja maupun tidak disengaja oleh manajemen.

$$
\text { Hasil pengujIan hipotesis }
$$

membuktikan bahwa tingkat pengungkapan laporan keuangan tidak mampu memoderasi hubungan antara tindak lanjut hasil pemeriksaan dan kualitas laporan keuangan. Bukti empiris ini mengindikasikan bahwa tingkat pengungkapan bukan pertimbangan utama auditor dalam menetukan kewajaran laporan keuangan. Seperti yang diungkapkan oleh Milal (2013) bahwa faktor utama yang menyebabkan belum tercapainya opini WTP secara penuh adalah masih adanya beberapa temuan Badan Pemeriksa Keuangan (BPK) dalam Sistem Pengendalian Intern (SPI) dan ketidakpatuhan terhadap peraturan perundang-undangan.

Jika terdapat kelemahan sistem pengedalian internal maka informasi keuangan yang disajikan tidak akurat dan tidak dapat diandalkan. Meskipun manajemen mengungkapkan informasi tersebut secara memadai. Namun hal ini tidak dapat menjamin bahwa informasi yang diungkapkan tidak mengandung bias informasi. Seperti yang diungkapkan oleh Rahayu \& Suhayati (2010, hlm. 23) bahwa informasi tertentu mungkin dipandang relevan sehingga perlu disajikan kepada pemakai. Namun jika hakikat atau penyajian informasi itu tidak dapat diandalkan maka menyajikannya kepada para pemakai justru dapat menyesatkan. Informasi harus dapat dipercaya, yakni bebas dari pengertian menyesatkan dan kesalahan material dan dapat dipercaya oleh pemakainya sebagai penyajian yang jujur. Selanjutnya menurut Rai (2011, hlm 30) kepatuhan terhadap peraturan perundang-undangan merupakan faktor dominan karena kegiatan di sektor publik sangat dipengaruhi oleh peraturan dan perundang-undangan. Karakteristik 
manajemen sektor publik sangat berkaitan erat dengan kebijakan dan pertimbangan politik serta ketentuan peraturan perundangundangan sehingga auditor sektor publik harus memberikan perhatian yang memadai pada hal-hal tersebut. Oleh karena itu, aspek kepatuhan terhadap peraturan perundanganundangan sangat menonjol pada setiap pelaksanaan audit sektor publik. Dengan demikian dapat disimpulkan bahwa pengungkapan tidak menjadi penilaian utama, melainkan auditor BPK lebih fokus terhadap efektivitas sistem pengendalian internal dan kepatuhan terhadap peraturan perundang-undangan.

\section{SIMPULAN DAN SARAN Simpulan}

Berdasarkan hasil penelitian yang dilakukan terhadap Laporan Keuangan Kementerian/ Lembaga Republik Indonesia pada tahun 2014, maka dapat ditarik kesimpulan sebagai berikut :

1. Hasil pengujian binary logistic regression menujukkan bahwa tindak lanjut hasil pemeriksaan berpengaruh positif terhadap kualitas laporan keuangan. Hal ini berarti tindak lanjut hasil pemeriksaan dapat memperbaiki kualitas laporan keuangan. Semakin tinggi tindak lanjut hasil rekomendasi maka semakin baik kualitas laporan keuangan.

2. Tingkat pengungkapan laporan keuangan berpengaruh positif terhadap kualitas laporan keuangan. Semakin tinggi tingkat pengungkapan laporan keuangan maka semakin baik pula kualitas laporan keuangan.

3. Pengaruh interaksi tindak lanjut hasil pemeriksaan dan tingkat pengungkapan laporan keuangan dalam penelitian ini tidak berpengaruh. Hal ini menunjukkan bahwa tingkat pengungkapan laporan keuangan tidak mampu memoderasi hubungan antara tindak lanjut hasil pemeriksaan dan kualitas laporan keuangan.

\section{Saran}

\section{Bagi Pemerintah Pusat}

Dalam rangka perbaikan pengelolaaan keuangan negara dan pencapaian target reformasi birokrasi, pemerintah pusat harus memberikan pembinaan pada Kementerian/Lembaga dan memberikan sanksi bagi K/L yang tidak menindaklanjuti hasil pemeriksaan. Hal ini cukup penting mengingat peningkatan kualitas laporan keuangan Kementerian/Lembaga dapat meningkatkan akuntabilitas pengelolaan keuangan negara, dan memberikan kontribusi untuk perbaikan opini LKPP.

\section{Bagi Kementerian Negara /Lembaga Republik Indonesia}

Kementerian Negara/ Lembaga harus memiliki komitmen yang kuat untuk menindaklanjuti rekomendasi hasil pemeriksaan dengan lebih optimal. Rekomendasi yang diberikan auditor dapat menjadi sarana untuk memperbaiki kualitas laporan keuangan dan mengurangi temuan audit. Selain itu dalam menyusun laporan keuangan, Catatan atas Laporan Keuangan harus lebih diperhatikan. Hal ini menjadi upaya yang konkrit untuk meningkatkan tingkat pengungkapan laporan keuangan. Sebab tingkat pengungkapan yang dilakukan merupakan dasar pengambilan keputusan bagi pihak-pihak yang berkepentingan.

\section{Bagi Auditor BPK}

Pemeriksaan laporan keuangan bertujuan untuk meningkatkan akuntabilitas publik serta penyajian informasi yang lebih jelas dan dapat diandalkan. Hasil pemeriksaan berupa temuan dan rekomendasi audit akan sangat berguna bagi perubahan dan perbaikan akuntanbilitas pengelolaan keuangan negara. Pelaksanaan rekomendasi menjadi kunci utama untuk mencapai perbaikan dan perubahan tersebut. Dalam penelitian ini dalam pengukuran tindak lanjut hasil pemeriksaan memasukkan rekomendasi yang tidak dapat ditindaklanjuti. Ini mengindikasikan bahwa rekomendasi yang diberikan auditor kurang dapat dipahami oleh Kementerian/Lembaga. 
FERA TRESNAWATI ${ }^{1}$ dan R. NELLY NUR APANDI ${ }^{2} /$ Pengaruh Tindak Lanjut Hasil Pemeriksaan Terhadap Kualitas Laporan Keuangan Dengan Tingkat Pengungkapan Laporan Keuangan Sebagai Variabel Moderating (Studi Empiris Pada Kementerian/Lembaga Republik Indonesia)

Oleh karena itu penyusunan rekomendasi yang baik perlu diperhatikan.

Keterbatasan dan Rekomendasi

$$
\text { Beberapa keterbatasan dan }
$$

rekomendasi dalam penelitian adalah sebagai berikut :

1. Tingkat pengungkapan laporan keuangan dalam penelitian ini adalah perbandingan antara pengungkapan yang telah disajikan dalam CaLK Kementerian/Lembaga dan pengungkapan yang seharusnya disajikan dalam CaLK berdasarkan checklist SAP. Penggunaan checklist tersebut mengandung unsur subjektivitas. Oleh karena penelitian selanjutnya diharapkan dapat menggunakan hasil review tingkat pengungkapan laporan keuangan dari BPK atau BPKP.

2. Penelitian selanjutnya dapat menggunakan variabel lain seperti kualitas sumber daya manusia dan pengawasan audit internal. Berdasarkan hasil pemeriksaan BPK terdapat kesalahan karena kurangnya pengalaman atau pengetahuan tentang bagaimana pencatatan atau perlakuan akuntansi. Kualitas SDM yang baik terutama operator penyusun laporan keuangan yang memiliki pengetahuan SAP yang memadai dan keterampilan dalam menyajikan laporan keuangan dapat menyebabkan tingkat pengungkapan menjadi tinggi. Sedangkan pengawasan audit internal mempunyai fungsi mereview laporan keuangan dan mendorong Kementerian/Lembaga dalam menindaklanjuti rekomendasi hasil pemeriksaan.

3. Penelitian baru dilakukan pada Kementerian/Lembaga. Pengembangan penelitian selanjutnya dapat dilakukan di BUMN dan BUMD.

\section{DAFTAR PUSTAKA}

Agusti, A.F. (2014). Faktor determinan akuntabilitas dan transparansi kementerian/lembaga. (Tesis), Fakultas Ekonomi, Universitas Indonesia, Depok
Akbar, B. (2015). Sistem pengawasan keuangan negara di Indonesia. Jakarta : Pusat Kajian Keuangan Negara.

Badan Pemeriksa Keuangan Republik Indonesia. (2015). Rapot merah tujuh Kementerian. Warta BPK edisi 06 Vol. V Juni 2015

Badan Pemeriksa Keuangan Republik Indonesia. (2008). Panduan manajemen pemeriksaan tahun 2008. Jakarta: BPK RI.

Badan Pemeriksa Keuangan Republik Indonesia. (2015). Ikhtisar hasil pemeriksaan semester 1 tahun 2015. Jakarta: BPK RI

Badan Pemeriksa Keuangan Republik Indonesia. (2014). Pemeriksaan Keuangan Negara (Diklat Teknis $K A P)$. Jakarta: BPK RI

Djalil, Rizal. (2014). Akuntabilitas keuangan daerah implementasi pasca reformasi. Jakarta : RMBOOKS PT Wahana Semesta Intermedia.

Ghozali, I. (2013). Aplikasi analisis multivariate dengan program IBM SPSS 21. Semarang: Badan Penerbit Universitas Diponegoro.

Hilmi, A. Z., dan Martani, D. (2012). Analisis Faktor-Faktor yang Mempengaruhi Tingkat Pengungkapan Laporan Keuangan Pemerintah Provinsi. Simposium Nasional Akuntansi XV. Banjarmasin.

Huang, R.B. \& Wang, Y.T, (2010). The empirical study on provincial government audit quality (20022006). Accounting Research 6, 70 76 (in Chinese).

Liestiani, A. (2008). Pengungkapan Laporan Keuangan Pemerintah Daerah Kabupaten/Kota di Indonesia untuk Tahun Anggaran 2006. (Skripsi). Akuntansi FE, Universitas Indonesia, Depok.

Milal, A. Z. (2013). Makna Opini Audit WTP Bagi Kementerian/Lembaga 
(Studi Kasus Pada Kementerian Sosial). Jurnal Ilmiah Mahasiswa $F E B, 1(2)$.

Mustikarini, W.A., dan Fitriasari, D. 2012. Pengaruh karakteristik pemerintah daerah dan temuan audit BPK terhadap kinerja pemerintah daerah kabupaten/kota di Indonesia tahun anggaran 2007. Simposium Nasional XV. Banjarmasin

Mutasowifin, A. (Penyunting). (2008). Memahami laporan keuangan (edisi ketujuh. Jakarta : PT Indeks

Nurdiono, dkk. (2015). Pengaruh proporsi anggaran dan faktor non keuangan pada hasil audit LKPD di seluruh Indonesia. Simposium Nasional Akuntansi XVIII. Medan.

Rai, I. G. A. (2011). Audit kinerja pada sektor publik: konsep, praktik, dan studi kasus. Jakarta: Penerbit Salemba.

Rahayu, S. K \& Suhayati, E. (2010). Auditing : Konsep dasar dan pedoman pemeriksaan akuntan publik. Yogyakarta : Graha Ilmu.

Sari, A.P., Martani, D \& Setyaningrum, D. (2015). Pengaruh temuan audit, tindak lanjut hasil pemeriksaan dan kualitas sumber daya manusia terhadap opini audit melalui tingkat pengungkapan laporan keuangan kementerian/lembaga. Simposium Nasional Akuntansi XVIII. Medan

Setyaningrum,D. (2015). Kualitas auditor, pengawasan legislatif, dan pemanfaatan hasil audit dalam akuntabilitas pengelolaan keuangan daerah. (Disertasi). Program Pascasarjana Ilmu Akuntansi, Universitas Indonesia, Depok.

Sugiono, A \& Untung, E. (2008). Panduan praktis dasar analisa laporan keuangan (pengetahuan dasar bagi mahasiswa dan praktisi perbankan). Jakarta: PT Grasindo.

Winanti, B. A. (2014). Analisis pengaruh temuan dan tindak lanjut pemeriksaan BPK, legitimasi kepala daerah serta pengawasan pemerintahan terhadap opini audit LKPD 2010-2011. (Skripsi). Akuntansi Fakultas Ekonomi, Universitas Indonesia, Depok.

Undang-Undang Nomor 15 tahun 2004 tentang Pemeriksaan Pengelolaan dan Tanggung Jawab Keuangan Negara. 
FERA TRESNAWATI ${ }^{1}$ dan R. NELLY NUR APANDI ${ }^{2} /$ Pengaruh Tindak Lanjut Hasil Pemeriksaan Terhadap Kualitas Laporan Keuangan Dengan Tingkat Pengungkapan Laporan Keuangan Sebagai Variabel Moderating (Studi Empiris Pada Kementerian/Lembaga Republik Indonesia) 